\title{
Tlingit Rattle as Archaic Culture Element and Sound Picture of the World
}

\author{
Angelina Alpatova \\ Russian State Gnessin Academy of Music \\ Moscow, Russia \\ e-mail: a_alpatova@mail.ru
}

\begin{abstract}
Archaic phenomenon acts at all levels of modern musical culture, from musical mentality as a base of creative process in musicians and composers practice to musical communications, which characterizes various kinds of social and cultural activity. The archaic reflection in music is one of the actual problem in the research of modern musicologists. It is possible to study archaic music elements in traditional and modern music forms and music ideology in a mass culture as musical-cultural archetypes of a contemporary epoch. Archaic and traditional music of different nations of the world is considered as a form of collective art memory that keeps the basic information structures of primitive and ancient cultures. It is seen in various ways: in mythological images and ceremonial practice, numerical symbolism and philosophical knowledge, and in elements of the musical text and in musicalcultural models. The reference to mythological sources gives the chance to present a sound picture of the world (SPW) in archaic culture. It corresponds with terms "world-hearing" (A. D. Caseres) and "ethnohearing" (I. I. Zemtsovsky). Mythological models of musical or musical culture mentality exists in the Northern American Indians (Kwakiutl) myth about Wakiash and a Frog. Tlingit rattle decorated the scene of the myth is both the element of archaic culture and the model of sound world picture.
\end{abstract}

Keywords-archeomusicology; mythology about music; sound world picture; Tlingit rattle.

\section{INTRODUCTION}

The theme of the article is devoted to the problem of archaic elements in North American Indians musical traditions studying in the mythological context. The problem is connected with archaic culture studies.

The study of Northern American Indians culture in Russia began in the nineteenth century. It became possible with the help of the Russian Orthodox Church missionaries' activity. The main part of their expeditions' materials was collected by Russian (especially St-Petersburg) museums with artifacts that were received from foreign travelers. For a long time many musical instruments were kept in museum archives and closed to a wide audience.

Until the seventieth year of the twentieth century in the Soviet musicology archaic and traditional music around the world was considered as primitive, and there were no experts who had the scientific interest to the musical artefacts. Famous Soviet musicologist R.I. Gruber used the results of studies by American musicologists of nineteen century and wrote about North American Indians music in the thirties and forties [3].

From the 1970s through to the 1990s there were World music cultures studied by Moscow musical culturology school (head G. K. Mikhailov, members H. V. Vassyltchenko, M. I. Karatygina, S. P. Volkova, V. I. Lisovoy, the author of the article), which included the research of American traditional music, as well as the music by American composers. In the beginning of the twenty first century the study of North American Indians culture and music by Russian philologist A.V.Vashchenko and musicologists S.Y.Sigida, and V.I.Lisovoy in their works use the comparative ways of the research.

\section{ABOUT THE RESEARCH APPROACHES TO ARCHAIC MUSIC ELEMENTS IN THE ARCHEOMUSICOLOGY AND MYTHOLOGY CONTEXT}

An archaic phenomenon acts at all levels of modern musical culture and musical mentality, which determine creative process in musical communication as a kind of social and cultural activity.

The archaic expression as it appears in music practice is one of many actual research problems modern musicologists deal with. Archaic elements can be studied in traditional and modern music forms and music ideology in a mass culture as musical-cultural archetypes.

In modern Russian ethnomusicology, archaic music is treated as typological phenomena, a basis of folklore traditions (N. Gilyarova, G. Lobkova, I. Matsijewsky, N. Savelyeva, V. Shchurov). In the book by the author of the article [1], archaic and traditional music around the world is considered as an art form of collective memory that keeps alive the basic informational structures of primitive and ancient cultures in various ways:

- Mythological images

- Ceremonial practice

- Numerical symbolic 
- Philosophical knowledge

- Elements of musical text

- Musical-cultural models

The study of the problem of archaic elements in musical traditions around the world needs to address archeomusicology as the new area of modern science. The development of Russian archeomusicology has its own specificity. They are both archeology and musicology with their scientific traditions, but with weak connections between them. Musicologists cannot take part in archeological expeditions. As a rule, all musical artefacts, instruments or their images in pictography are collected in museums.

Today in Russia there are only several experts who can study these materials: the theorist and critic V. Meshkeris (St.-Petersburg), and the masters for musical instruments A. Gnezdilov (Barnaul) and V. Maraev (St.-Petersburg). Their works discover the new direction of the science in Russia.

One of the main sources of archeomusicological studies can be mythology. Mythology and music are independent phenomena characterizing different levels of cultural development.

Mythology can be considered as the special (ancient) historic stage of culture and cultural mentality; the first forms of spiritual culture. The establishment of harmony, balance between nature and a person, mysterious and humanized characteristics are in mythology as well as in music.

In mythology the structure of thinking, linguistic base and specificity of economic and cultural development was expressed. A person found and offered an explanation of all processes around the world with the help of mythology. Universe, space, natural phenomena, animals, people, human life, economic conditions, culture and art creativity become the main themes of myths. Myth development and transformations of the world are carried out by symbolical signs' means, but the cultural information is presented in clear forms of bright, colorful images. Thus a myth reaches a harmony establishment between a world, a society, a nature and a person.

In the twentieth century the mythological context was included in both musicology and cultural anthropology. In musicology music is treated as an art culture originating in the past but acting in perfect forms of a new historic period. Such musical works by outstanding composers as oratorios by G. F. Handel, operas by C. G. A. Monteverdi, C. W. R. von Gluck, W. R. Wagner, N. A. Rimsky-Korsakov, and I. F. Stravinsky were written on mythological plots and can be analyzed by both musicologists and anthropologists.

Modern Russian musicologists have studied the Slavs' instrumental music of the ninth to sixteenth centuries in its connections with mythology (R. Galayskaya), and analyzed the mythological context of music by I. F. Stravinsky and other composers at the beginning of twentieth century including the influence of literature on the music (L. Gerver).

In archeomusicology the mythological category can be considered as one of the basic methods for archaic music studies. C. Levi-Strauss compared different mythological and musical structures and found their common rules. The research of mythological context of traditional music has its specificity. For understanding, it's necessary to examine the common cultural and social elements of ritual practice with sound experience of the communication with the Universe, nature and spirits of ancestors in traditional society.

In traditional culture music connects with deep mythological sources, this is not by accident. The interaction of mythology and music keeps a value of sound and music practice, which was formed in early human cultures. Communication between mythology and music occurs in a sphere of ceremonial and ritual practice and in a holiday context of traditional culture. It opens perception, imagination, and feelings, and expresses the mentality of a person; which represents the culture and ideology of epoch.

The harmonizing function of a myth is in emotional and sensual creativity, and is reflected in sound art images. Cultural forms of traditional syncretism (epos, dramatized representation, musical-plastic game, ceremonial action, ritual procession) are the results of constant processes of interactions between mythology and music in world history.

Music uses diachronic (a narration about historic events in ancient epoch) and synchronic (connection of present and future cultures) levels of a myth so the musical text always fixes «an instant between past and future» and at the same time contains all information in compressed form. In music the mystical mythological qualities are not visible, not perceived, but heard.

As a rule in traditional cultures around the world mythological knowledge is perceived as a gift of gods, cultural heroes, and ancestors; it is considered as sacral and is kept with close information. Various events of mythological space attract attention to the universal role of sound and music.

Next levels of the mythological knowledge about sound and music can be researched:

- Value of a sound (sound vibration, vibration) in creation, formation and development of the world, including creation of the world from a sound.

- Deities of nature phenomena, forces or elements participating in creation of the world by sound means.

- A birth of the first people by means of sound, music and musical instruments.

- Deities, spirits, ancestors and cultural heroes with sound, music and musical instruments as their sacral attributes. 
- Sound, music and musical instruments as weapon in a struggle against evil ghosts.

- Singers, actors and musicians as keepers of cultural traditions with leaders, shamans and priests.

Ceremonial and ritual practice in traditional culture is very often based on myths, which create the integral forms with:

- Epic and musical actions

- Choreographic and pictorial interpretations

- Dramatized representations

- Ritual processions

\section{The Tlingit RATTLE AND THE MYTH ABOUT CHIEF WAKIASH}

Tlingit rattle, in the image of a man and a frog flying on a raven unexpectedly, reminds the Kwakiutl Indians of the myth about the chief Wakiash.

At the beginning of the twentieth century the myth about communication between a man and spirits of ancestorsanimals with music was told by Kwakiutl Indian Ch.J.Nouvell, to American ethnomusicologist N.Curtis who collected the story and the song about the chief Wakiash [2:299-302]. The plot of the myth about the chief Wakiash is very simple but the mythological context in the story is connected with real tribal life of Indians. The chief Wakiash never had any kind of own (chief's and medicine) songdance and he was unhappy.

The main events-episodes of the myth are next:

- The chief Wakiash's dreaming about own song-dance on mountain during four days;

- The chief Wakiash's meeting with a frog and a raven and a flight with them to the country of the spirits of ancestors-animals;

- Sacred masked dances with singing of spirits of ancestors-animals (a beaver-leader, a mouse-woman etc.);

- Receiving from the spirits of ancestors-animals a totem pole Kalakujuvish, personal dances with songs and sacred musical instruments;

- Returning of the chief Wakiash with the frog and raven to their country at night four days, (four years for people of Earth), later and the development of musical traditions in the tribe.

The myth about the chief Wakiash contains four main types or levels of musical and cultural mentality models: moving - transformation - receiving - inspiration. They were connected with ritual (especially shamanistic) practice, which characterized Kwakiutl, Tlingit and Winnebago Indians traditions. The music in the myth about the chief Wakiash symbolizes and personalizes supernatural power which spirits of ancestors-animals give him with song-dance and ritual artefacts for a human being.

It's characteristic for the mythological events that the spirits of ancestors-animals couldn't start to dance and to sing without skins (it was the rule for sacred masked dancing with singing) when unknown for them the chief Wakiash was near their house. Later a mouse turned to a woman and offered the chief Wakiash to enter. He introduced himself and spirits of ancestors-animals started to dance and to sing. Two-masked dance for the chief Wakiash were the dance of Echo's mask with different voices and the dance of Small person's mask with shouts.

Kwakiutl Indians, as well as Tlingit and Winnebago are included in the Northwest Coast culture of Northern America. Northwest Coast is a slim strip about hundred miles wide between the Pacific Ocean and the Cascade Range extending from the panhandle of Alaska to northern California in the USA. The people in this area live in large wood houses in the winter but travel to gather, hunt and fish during the remainder of the year.

Specific features of Northwest Coast Indians music are:

- The role of music in shamanism, healing and contacts with spirits of ancestors or gods with using of tobacco, alcohol or hallucinogens.

- The associations of music with powerful spirits, ancestors, animals or gods.

- The unity of music and dance.

The association between music and spirituality is expressed in the shamanistic music and shamans' songs, which are used all year round. The main shaman's ritual instruments are a rattle and a frame drum. It is typical that the number of sound repetitions or sections in the music making is related to significant mythological and cosmological ideas.

During previous centuries the music of Northwest Coast Indians was used to accompany social dances, games, calendar rituals and events in the life cycle. There was a preponderance of vocal music and elaborated speech styles over instrumental ensembles.

The songs of Northwest Coast Indians belong to three basic types. Ceremonial songs include totemic crest songs and potlatch songs, many songs are connected with specific rites (for instance the Kwakiutl Indians «hamatsa» is a performance to restore to society the young initiates from the land of supernatural beings). Different songs connect with fishing and hunting and are performed in the initiations ceremonies. Usually certain wooden carved rattles accompany these ceremonies and songs [4:890-891; 5].

In archaic cultural traditions a musical instrument as well as a human voice could be connected with both nature and people. The rattle was one of the earliest known instruments that were used in ancient cultures widely. 
Terracotta rattles in animals' forms were known four millenniums ago in Mesopotamia. Plaited rattle, a rattle with a handle and a rattle with straw, reed or papyrus elements were used in Egypt. In modern European, Asian and African culture rattles in animals' or birds' forms are used by children.

The Tlingit wooden carved rattles with the handles from the "Kunstkamera" have anthropomorphic and zoomorphic images "Fig. 1" \& "Fig. 2".

They show the Kwakiutl Indians chief Wakiash which flies on a raven with a frog sitting on his breast and speaking with him. Their conversation is transferred with the help of an image of a frog's long tongue. A raven body is a deitypatron's head.

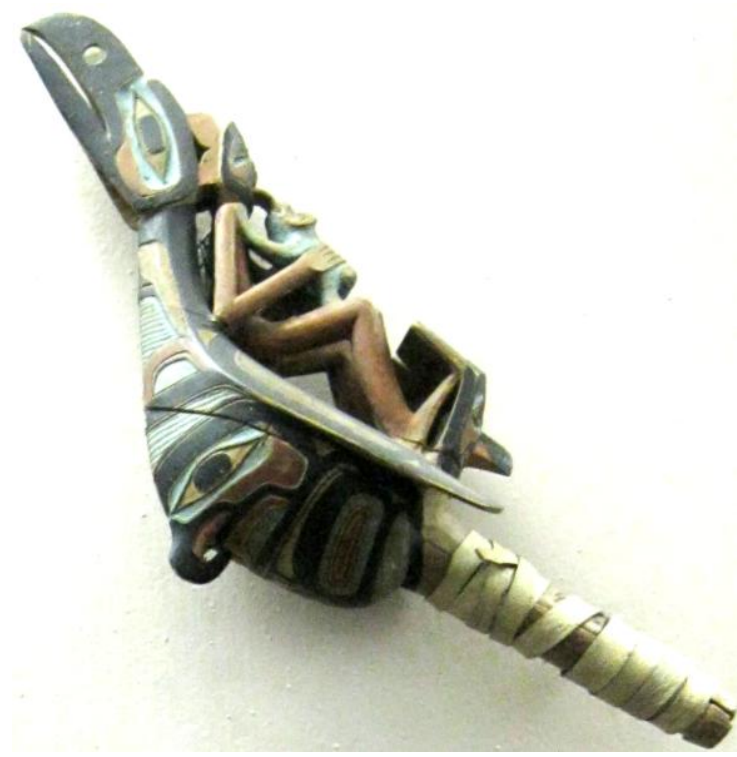

Fig. 1.

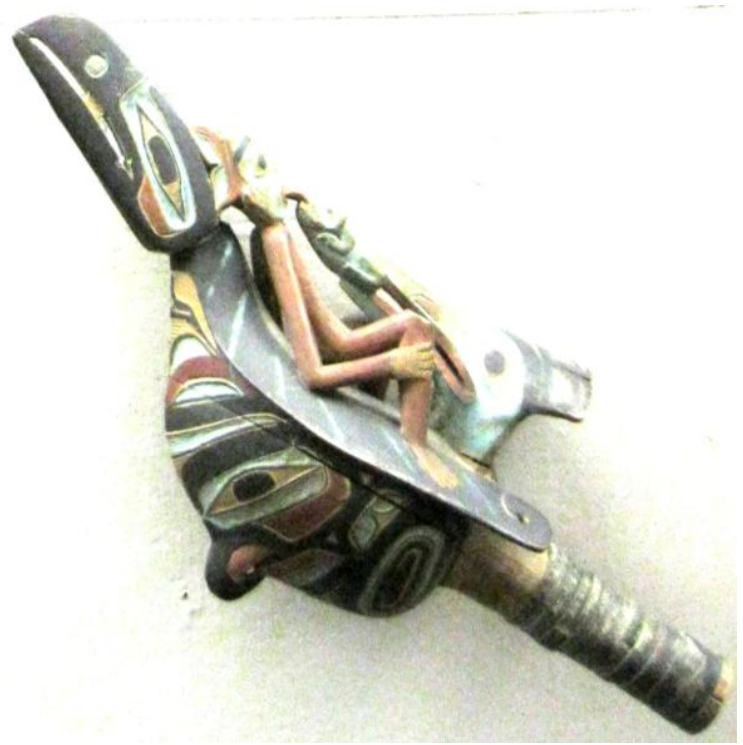

Fig. 2.

\section{CONCLUSION}

Tlingit rattles had little stones inside and the movement (shaking) of a rattle in musician's hands could symbolize the flight. A deity-patron, the chief Wakiash and a frog mark three levels of the mythological world of archaic culture: upper (heavens), middle (people) and down (underground). A raven is the intermediary (medium) between them. Thus the images and the sounds of Tlingit rattle represent the SPW of the North American Indians. The mythological manifestations of the cultural models and musical mentality reflect the scientific and art context of archaic culture and music.

\section{REFERENCES}

[1] Alpatova A.S. Archaic Phenomena in World Musical Culture. Moscow, 2009. 204 p. (in Russian)

[2] Gruber R.I. The General History of Music. Moscow, 1946. (in Russian)

[3] Curtis N. Indian book. Songs and legends of the American Indians. N.Y., 1968.

[4] Keillor E.P. Amerindian music. - The New Grove Dictionary. London, New York, 2002.

[5] McAllester D. North America/Native America // Worlds of Music, ed. J. Todd. New York, 1984. P .12-63. 